\title{
Inequities in the freedom to lead a flourishing and healthy life: time for a progressive social protections framework
} Comment on "Inequities in the freedom to lead a flourishing and healthy life: issues for healthy public policy"

\section{Gemma Carey ${ }^{\star}$}

\section{Abstract}

Evidence now shows that the key drivers of poor health are social factors, such as education, employment, housing and urban environments. Variations in these social factors-or the conditions in which we live our lives-have lead to a growth in health inequalities within and between countries. One of the key challenges facing those concerned with health equity is how to effect change across the broad policy areas that impact these social conditions, and create a robust 'social protections framework' to address and prevent health inequalities.

Keywords: Healthy Public Policy, Health Equity, Social Protections Policies

Copyright: @ 2014 by Kerman University of Medical Sciences

Citation: Carey G. Inequities in the freedom to lead a flourishing and healthy life: time for a progressive social protections framework; Comment on "Inequities in the freedom to lead a flourishing and healthy life: issues for healthy public policy”. Int J Health Policy Manag 2014; 3: 223-225. doi: 10.15171/ijhpm.2014.90
Article History:

Received: 8 September 2014

Accepted: 23 September 2014

ePublished: 24 September 2014

*Correspondence to:

Gemma Carey

Email: gemma.carey@anu.edu.au
$\mathrm{P}$ ublic health research evidence has shown that many of the key drivers of health reside in our everyday living conditions $(1,2)$. Socio-economic position can predict who develops and eventually succumbs to heart disease, diabetes, respiratory disease and particular cancers (1). As Friel argues in her editorial Inequities in the freedom to lead a flourishing and healthy life: issues for healthy public policy, health equity gaps continue to grow, despite unprecedented global wealth and technological progress (3).

Friel's illustrative story of Anna captures the multi-layered and enmeshed ways in which social inequities work to diminish the capacity of individuals and groups to lead a healthy life. As Friel notes, tackling such inequalities is a challenge - for individual politicians, societies and progressive public policy. It is this final point that I wish to focus on in this commentary. The description of Anna's circumstances demonstrates the broad range of public policy areas that impact health. One of the greatest challenges facing the public health community is how to secure the organisation of these diverse areas of public policy in such as way as to ensure they are health promoting. Using Anna's story, I discuss how we might create a robust 'social protections framework' to address and prevent inequality.

Anna has access to important universal services, such as health and education. We know from emerging research on the relationships between population health and the structure of a country's social protections framework (traditionally referred to as the 'welfare state') that universal services are protective for the health of individuals and reduce inequalities $(4,5)$. However, the last twenty years have seen the deterioration of many public services (6). From this, dual (or, more accurately, tiered) systems have emerged as individuals have sought out better, private, alternatives (7), such as private hospitals and schools $(8,9)$. As those who can afford to purchase alternatives leave the public system, public services deteriorate further; those most empowered to fight for public programs (i.e. individuals higher up the social gradient) no longer have a stake in ensuring the quality of public goods delivered by government (10). For Anna, this resulted in a poor quality educational experience, including a lack of staffing, resourcing and support to help students reach for greater educational and life opportunities. Anna's story demonstrates that addressing inequality and protecting the health of future generations requires strong and well-funded universal public services, including in non-health areas such as education.

When Anna left school, she found herself in an inequitable labour market where her earning power was limited. Labour market deregulation in Organisation for Economic Cooperation and Development (OECD) countries over the last 30 years has seen the removal of external protections for workers (11). This has included minimum wage standards, penalty rates, and provisions that ensured appropriate remuneration overtime or long hours (12-14). The removal of collective bargaining arrangements for workers has stripped power away from individuals to secure the types of work entitlements they need to flourish. Indeed, reduced union membership across OECD nations has been linked to growth in social inequalities $(15,16)$. A robust social protections framework would protect the rights of workers, and reduce the growth of precarious or low paid work like Anna's, which is damaging to both the health of individuals and families (17). 
While universal public services are critical, Anna's story draws attention to the fact that some groups receive less benefit from universal services than others $(18,19)$. Social identitiesarising from age, gender, cultural or background-mean that different individuals and groups have different needs (20). As a result, universal services may cater better for some individuals than others. For example, services that meet the needs of Anglo-Saxon families may be wholly inadequate for indigenous families or other cultural groups (21). To address this, we need to ensure diversity in the supply of publicly funded services, so that they may take account of social diversity.

In social policy, this is known as 'particularism' - where a range of services are created in order to try and respond to the different needs and social identities of different groups (22). This requires an appreciation of the values, wants and norms of different sections of society $(7,22)$. Purchaser-provider models in disability care are an example of particularist principles in action, where state funds are given to individuals so that they may 'purchase' a service from providers (23). This approach is believed to empower individuals to make choices about the services and care they receive, ensuring they are better catered to their needs (24).

The description of stagnating house prices, poor urban planning and lack of local amenities such as parks and public transport suggests that Anna lives in an area of concentrated disadvantage. Anna's neighbourhood draws attention to the need some groups, or areas, have for additional investment and resources. While universal services are important they are insufficient for overcoming existing inequalities (25). Addressing existing inequalities requires specific 'targeted' efforts to address those with greater needs, in addition to universal social protections.

What is known as 'place-based' initiatives-a form of policy targeting-has become an increasingly common way for governments to try to lift economically depressed areas (26). Here, areas or 'postcodes' of concentrated disadvantage are targeted for increased investment and implementation of programs, often designed collaboratively with local communities (27).

Indeed, empowering people like Anna to find solutions to the challenges they face is critical to success. As Friel notes, drawing on the work of Backsher and Lovasi (28), involving individuals like Anna in the design of programs leads to better outcomes - whether addressing build environment problems or ensuring usable and effective social services (29). From a public policy perspective, the best way to ensure this type of participatory policy-making is to create governance structures that ensure decisions are made as close to the individuals they affect as possible. This is known as the subsidiarity principle, which is both a principle of governance and a practical framework for solving social problems $(30,31)$. At its simplest, subsidiarity seeks to ensure that decisions and actions are taken as closely as possible to citizens. Subsidiarity is a "principled tendency toward solving problems at the local level and empowering individuals, families and voluntary associations to act more efficaciously in their own lives" (31).

In the case of placed-based initiatives to address the type of built environment problems faced by Anna, subsidiarity would see local governments working collaboratively with citizens. However, subsidiarity can also play an important role in the design of tailored services, or particularism, as discussed earlier. Here, decisions regarding what services need to be tailored to which individuals are made at the level of governance closest to those individuals, in partnership with non-government entities (such as NGOs or voluntary associations). These organisations are embedded in local communities, making them more likely than federal governments to understand the needs of specific individuals and groups and how best to address them (32-35). As put by Friel, "Health equity requires inclusion and agency, requiring individuals and groups to represent their needs and interests strongly and effectively".

Of course, these efforts are largely redistributive - addressing issues once they have emerged. As Friel describes, Anna's wellbeing is dramatically shaped by the unequal distribution of power and resources. Here, we need to go beyond redistributive efforts to embrace more progressive approaches to public policy. In the UK, 'pre-distribution' has gained interest as a way to tackle the inequitable distribution of power and resources and, by extensive, improve the health of individuals and populations. Predistributive policies attempt to shift how markets distribute resources from the outset (as opposed to redistributing wealth in order to 'clean up' marketdriven inequalities) (36). Pre-distribution focuses on " $m a r k e t$ outcomes that encourage a more equal distribution of economic power and rewards even before government collects taxes or pays out benefits" (37). Some universal protections are in fact predistributive policies, including industrial relations policies that protect the growth of unequal wages or the removal of collective bargaining (23). Others, such as company tax reform, sit along side universal policies to ensure the system is fairer and not systematically rigged against some individuals or groups.

These different approaches to policy and service provisionfrom predistributive and universal efforts, to targeting and particularist approaches-can coalesce to form a protective framework that prevents inequalities widening. Such a framework is also sufficiently targeted-or graded-to redress inequalities that have already emerged. This is in stark contrast to the types of fractured, overlapping, and often adhoc, arrangements that characterise the social protection systems currently in place in many countries. Moving the health equity agenda forward requires policy frameworks that ensure we hit the right policy levers and utilise the right governance structures to have a real impact.

Ethical issues

Not applicable.

Competing interests

The author declares that she has no competing interests.

Author's contribution

$\mathrm{GC}$ is the single author of the manuscript.

\section{References}

1. Marmort M. Fair Society, Healthy Lives: The Marmot Review. Strategic Review of Health Inequalitites in England post-2010. 


\section{Key Points}

- Public health research evidence has shown that the key drivers of health fall across diverse policy areas and portfolios of government.

- Currently, those concerned with health equity are grappling with how to organise the diver areas of public policy that impact health in a way that reduces-not widensinequalities.

- To achieve this, there is a need for a strong social protections framework, which incorporates both universal and targeted policies while taking account of social diversity.

- Such a framework must be accompanied by effective governance structures that ensure action is taken at the most effective level.

London; 2010.

2. Commission on Social Determinants of Health (CSDH). Closing the gap in a generation: health equity through action on the social determinants of health. Geneva: WHO; 2008.

3. Friel S. Inequities in the freedom to lead a flourishing and healthy life: issues for healthy public policy. Int $J$ Health Policy Manag 2014; 3: 1-3. doi: 10.15171/ijhpm.2014.82

4. Coburn D. Beyond the income inequality hypothesis: class, neoliberalism, and health inequalities. Soc Sci Med 2004; 58: 41-56. doi: 10.1016/s0277-9536(03)00159-x

5. Brennenstuhl S, Quesnel-Vallee A, McDonough P. Welfare regimes, population health and health inequalities: a research synthesis. J Epidemiol Community Health 2012; 66: 397-409. doi: 10.1136/jech-2011-200277

6. Stark P. The politics of welfare state retrenchment: A literature review. Soc Policy Adm 2006; 40: 104-20 . doi: 10.1111/j.14679515.2006.00479.x

7. Thompson S, Hoggett P. Universalism, selectivism and particularism: Towards a postmodern social policy. Crit Soc Policy 1996; 16: 21-42. doi: 10.1177/026101839601604602

8. Hurley J, Vaithianathan R, Crossley TF, Cobb-Clark DA. Parallel private health insurance in Australia: A cautionary tale and lessons for Canada. IZA Discussion Paper; 2002. Report No.515.

9. Taylor-Gooby P. Postmodernism and Social Policy: A Great Leap Backwards? J Soc Policy 1994; 23: 385. doi: 10.1017/ s0047279400021917

10. Stiglitz J. The demand for education in public and private school systems. J Econ 1974; 3: 349-85. doi: 10.1016/00472727(74)90005-x

11. Campbell I, Brosnan P. Labour Market Deregulation in Australia: the slow combustion approach to workplace change. International Review of Applied Economics 1999; 13: 353-94. doi: 10.1080/026921799101599

12. Briggs C, Buchanan J. Australian Labour Market Deregulation: A Critical Assessment. Parliament of Australia; 2000.

13. Watson I, Buchanan J, Campbell I, Briggs C. Fragmented Futures: New Challenges in Working Life. Sydney: Federation Press; 2003.

14. Sala H, Silva JI, Toledo M. Flexibility at the Margin and Labor Market Volatility in OECD Countries. Scand J Econ 2012; 114: 991-1017.

15. Pocock B. Rethinking unionism in a changing world of work, family and community life. Relations Industrielles/Industrial Relations 2011; 66: 562-84. doi: 10.7202/1007633ar

16. Chung $\mathrm{H}$, Muntaner $\mathrm{C}$, Benach J, the EMCONET Network. Employment Relations and Global Health: A Typological Study of World Labor Markets. Int J Health Serv 2010; 40: 229-53. doi: 10.2190/hs.40.2.e

17. BenachJ, MuntanerC, SantanaV, Chairs F. Employmentconditions and health inequalities. Final report to the WHO Commission on
Social Determinants of Health (CSDH) Employment Conditions Knowledge Network (EMCONET) [Internet]. Geneva: WHO. 2007 [cited 2014 May 8]. Available from: http://cdrwww.who.int/entity/ social_determinants/resources/articles/emconet_who_report.pdf

18. Hart JT. The inverse care law. Lancet 1971; 297: 405-12. doi: 10.1016/S0140-6736(71)92410-X

19. Victora CG, Vaughan JP, Barros FC, Silva AC, Tomasi E. Explaining trends in inequities: evidence from Brazilian child health studies. Lancet 2000; 356: 1093-8. doi: 10.1016/s01406736(00)02741-0

20. Anttonen A. Universalism and the challenge of diversity. In: Anttonen A, Haikio L, Stefansson K, editors. Welfare State, Universalism and Diversity. Cheltenham: Edward Elgar; 2012. p. $1-15$.

21. Henderson G, Karn V. Race, Class and State Housing: Inequality and the Allocation of Public Housing in Britain. Aldershot: Gower; 1987.

22. Spicker P. Understanding particularism. Crit Soc Policy 1994; 13: 5-20. doi: 10.1177/026101839401303901

23. Carey G, Crammond B. A glossary of policy frameworks: the many forms of "universalism" and policy "targeting". Journal of Epidemiology and Community Health; forthcoming.

24. Neal R, Parker R, Brown K. Purchaser-Provider Split in a Traditional Public Service Environment: Three Case Studies of Managing Change. Public Policy Administration Journal 2000; 9: 206-21.

25. Dworkin R. Taking Rights Seriously. Cambridge, MA: Harvard University Press; 1978.

26. Morenoff J, Lynch J. What makes a place healthy? Neighborhood influences on racial/ethnic disparities in health over the life course. In: Anderson NB, Bulatao RA, Cohen B, editors. Critical perspectives on racial and ethnic differences in health in late life. Washington, DC: National Academies Press (US); 2004.p. 406-49.

27. Mitchell R, Dorling D, Shaw M, Joseph Rowntree Foundation. Inequalities in life and death: what if Britain were more equal? Bristol: Policy Press; 2000.

28. Blacksher E, Lovasi GS. Place-focused physical activity research, human agency, and social justice in public health: Taking agency seriously in studies of the built environment. Health Place 2012; 18: 172-9. doi: 10.1016/j.healthplace.2011.08.019

29. Bradwell P, Marr S, PricewaterhouseCoopers LLP. Making the most of collaboration: An international survey of public service co-design [Internet]. Demos London; 2008 [cited 2014 Sep 8]. Available from: http://www.mbsportal.bl.uk/secure/subjareas/ $\mathrm{mgmt} /$ demos/111678making08.pdf

30. van Kersbergen K, Verbeek B. Subsidiarity as a Principle of Governance in the European Union. Comparative European Politics 2004; 2: 142-62. doi: 10.1057/palgrave.cep.6110033

31. Syrpis P. In defence of subsidiarity. Oxf J Leg Stud 2004; 24: 323-34 doi: 10.1093/ojls/24.2.323.

32. Cole I, Etherington D. Neighbourhood Renewal Policy and Spatial Differentiation in Housing Markets: Recent Trends in England and Denmark. European Journal of Housing Policy 2005; 5: 75-77. doi: 10.1080/14616710500055703

33. Keast RL, Mandell M. The collaborative push: pushing beyond rhetoric and gaining evidence [internet]. 2011 [cited 2014 Jul 24]. Available from: http://eprints.qut.edu.au/47352/

34. O'Flynn J. Crossing boundaries: The fundamental questions in public. In: O'Flynn J, Wanna J, editors. Crossing Boundaries in Public Management and Policy: The International Experience. London: Routledge; 2013. p. 11-44.

35. Bills D. Tackling social exclusion: The contribution of voluntary organisations. In: Harris M, Rochester C, editors. Voluntary Organisations and social policy in Britain. London: Palgrave; 2001. p. 37-48.

36. Hacker J. The institutional foundations of middle-class democracy [Internet]. Policy Network; 2011. Available from: http://www. policy-network.net/articles/3998/The-institutional-foundationsof-middle-class-democracy

37. Hacker J. Making Progressive Politics Work. London: Policy Network; 2014. p. 34-7. 